\title{
User Based Design Model to Enhance Satisfaction by Using Government Online Information
}

\author{
Massila. Kamalrudin, Hamdan Hmoud Sroukh Alderei, Safiah Sidek, Halimaton Hakimi
}

\begin{abstract}
Government information online is a transformation of relations between the internal and external public sector, through ICT, to enhance government service delivery and participation in the citizenry. By using government information online, a lot of advantages can be obtained, and it is important for users from different generations to obtain positive benefits from them. As the world is quickly growing without boundaries, the Internet and the worldwide web have become a common means of providing government information and services to the public, the companies and other governmental organizations. This paper reports a review on the analysis of the usage patterns of government online information for different generation cohort and existing work related to satisfaction of online information. The analysis were based on two questions that address the usage patterns of government online information and existing works related to satisfaction. Based on seventy selected articles reviewed, it was found that we found that 'education purpose' is the most commonly investigated usage pattern and most of related works of satisfaction focusing in developing model and framework.
\end{abstract}

Keywords---User Based Design, Online information, Generation.

\section{INTRODUCTION}

Government online information is actually very important as it acts as important agent to delivering all the policies or any other crucial information from government to citizens. It is essential for country to implement government information online as it helps to smooth the state's administration system, especially in the developed country. That is why the low number of usage of government information online will become a liability to the country itself. However, considered the current era, known as the Information Age of the 21st century, which is characterized by the rapid shifts from the traditional industry to the industrial revolution, from the computer age, the digital age to the new media age (Matiyas, 2015), the most challenging tasks is to ensure the government information online is inclusive to the all generations, which can be identified into three categories, namely the digital natives, digital immigrant and digital immigrants.

For enhancing government information online, the usage pattern of the users from different generations need to be taken into consideration in order to synchronize it with the

Revised Version Manuscript Received on September 16, 2019.

Massila. Kamalrudin, Faculty of Information and Communication technology, Universiti Teknikal Malaysia Melaka, Melaka, Malaysia.

Hamdan Hmoud Sroukh Alderei, Abu Dhabi Police Department, Abu Dhabi, United Arab Emirates

Safiah Sidek, Institute Technology Management and Entrepreneurship, Universiti Teknikal Malaysia Melaka, Melaka, Malaysia

Halimaton Hakimi, Faculty of Information and Communication technology, Universiti Teknikal Malaysia Melaka, Melaka, Malaysia.

problem faced by the users. In this context, the enhancement of the user response actually depends on the problem facing and the usage pattern by the user which come from different generations. However, there have been very limited works to capture or analyze the usage pattern specific for each of the three generations. Most of the works tend to study on the enhancement of the users response generally (Ball et al., 2017), rather than the division of digital generation. In fact, in order to enhance the satisfaction of the user of government online information, it is essential to identify the usage pattern used by them and what types of problem faced by users. Therefore, enhancing the satisfaction and loyalty to the different users of government information online in one of the ways to create a better learning process for all the generation which will became a great prospect for their future.

Hence, this study presents a Systematic Literature Review (SLR) that reports two findings for user based design in using government online information. The first finding is to identify the usage pattern of government online information for different generations cohort, and second is to identify the existing works to enhance government online information. This paper is organized into four main sections. After the introduction, the second section presents the methodology of the review. The third presents the findings and discussion section. Finally, conclusion presented in the fourth section.

\section{RESEARCH METHODOLOGY}

We constructed a review protocol to search for the relevant studies based on Kitchenham [3] systematic review approach. As our research is more focuses on wider knowledge in readiness model and smart government. The basic phases of [3] are divided by three phases which are planning, conducting and reporting. In the planning phase, we designed research questions as in Table 1 . These research questions are designed to address the organization issues as aforementioned.

Table 1: Research questions

\begin{tabular}{|l|l|}
\hline RQ1 & $\begin{array}{l}\text { What are the usage patterns of government online } \\
\text { information for three groups of digital } \\
\text { generation? }\end{array}$ \\
\hline RQ2 & $\begin{array}{l}\text { What are the existing works to enhance } \\
\text { satisfaction and loyalty of using government } \\
\text { information online? }\end{array}$ \\
\hline
\end{tabular}


Activities of the review protocol are shown in Figure 1. The aim of the review protocol is to ensure the complete analysis is supported by all the appropriate research. ScienceDirect, IEEE Xplore, Springer, Scopus, Google Scholar and ACM Digital Library were the search engines for the empirical research. The search keywords were used to ensure that all related documents were included in various topics. (User Based Design OR User Centered Design Model) AND (Pattern OR Usage Pattern) AND (Online Information OR Information) AND (Approach OR Method OR Framework OR Model) AND (Government) to collect all the relevant papers.

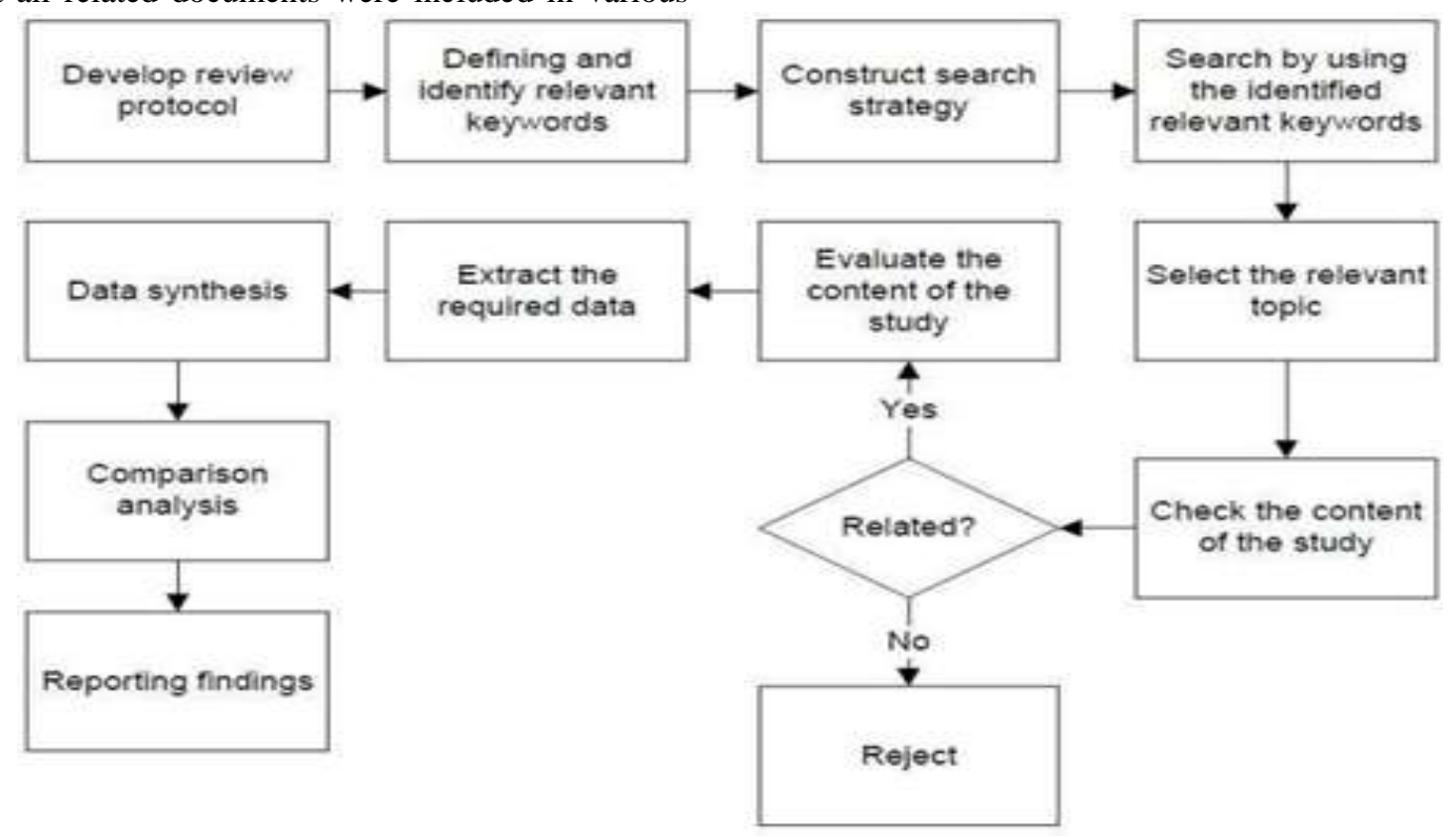

Figure 1: Review protocol process [3]

We applied inclusion and exclusion criteria as outlined in Table 2 to collect relevant studies. By analyzing the title, abstract, and conclusion of the primary identified studies, we eliminated any unrelated studies. After applying these steps, 89 studies were retained. Furthermore, we accessed and evaluated the articles by checking the content of the articles. Irrelevant studies were rejected at this stage and the relevant studies will be analyzed. Out of 89 articles, only 70 articles were considered for further review. The next phase was to conduct the comparison analysis and report the analysis of the related works.

Table 2: Inclusion and Exclusion Criteria

\begin{tabular}{|c|c|}
\hline Inchusica Criteris & Erchovien Criteria \\
\hline $\begin{array}{l}\text { Pepers fousing on usa based design nodd in gotemmen: } \\
\text { oulint inforustion }\end{array}$ & 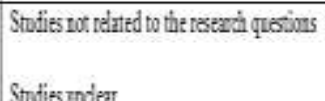 \\
\hline $\begin{array}{l}\text { Papas focusing cu frmevouks, nodels, nethots and aproath } \\
\text { used in user hasad design in govenneat oline infumativn }\end{array}$ & \\
\hline
\end{tabular}

\section{FINDING AND DISCUSSION \& RESULTS}

We found 13 significance patterns of usage, identified from the 70 studies related to the government information online enhancements for the users. For the purpose of this review, we focus on the most top structured usage pattern of government information online for different generation. The results are presented in Table 3. 
Table 3: Usage pattern of government online information for different generations

\begin{tabular}{|c|c|c|c|c|c|}
\hline \multirow{2}{*}{\multicolumn{2}{|c|}{ 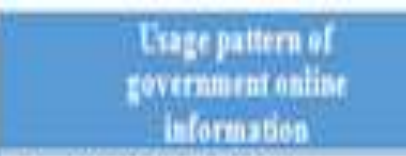 }} & \multirow{2}{*}{$\begin{array}{l}\text { Noot } \\
\text { paper } \\
\text { indy }\end{array}$} & \multicolumn{3}{|c|}{ Inte of tententon collition } \\
\hline & & & Digital Natires & Digital Intermediates & Digital Immiggrants \\
\hline 1 & Pubbic policy or issue & 12 & [I] & {$[2],[3],\{4,[1],[3],[6],[]]$} & $\begin{array}{c}{[8,[9],[10],[4],[1],[11]} \\
{[12],[5,(6)}\end{array}$ \\
\hline 2 & Govenment agencysenites & 9 & [13] & $\begin{array}{c}(9),(3),(10),(13),[11),(12), \\
{[3,[14]}\end{array}$ & (15), $[14]$ \\
\hline 3 & Religous info & 9 & [15] & [15].[3].[16].11] & [15],[10][12] \\
\hline 4 & $\begin{array}{l}\text { Officilgovemmert } \\
\text { documentsorstatitis }\end{array}$ & 8 & [17] & $\begin{array}{l}{[2],[3][10],[18],[17],[12]} \\
{[i 4]}\end{array}$ & [10],[13][17] \\
\hline 5 & $\begin{array}{l}\text { Rectedbotal ortcunat } \\
\text { information froma } \\
\text { govemmert agency }\end{array}$ & 11 & $\begin{array}{l}{[191,20],[10],(4),} \\
{[21],[12],[3],[2]}\end{array}$ & {$[19\},[10\},[11],(14]$} & {$[19],[7]$} \\
\hline 6 & $\begin{array}{l}\text { Advice onthaither afety } \\
\text { issue }\end{array}$ & 16 & [23] & $\begin{array}{c}{[10),[24,[11,[13],(18),[25],} \\
{[26],[11],[27]}\end{array}$ & $\begin{array}{c}[28],[19],[10],[24],(4)] \\
{[11,[13],[18],[26],[27]} \\
{[29],[5]}\end{array}$ \\
\hline$?$ & $\begin{array}{l}\text { Applied for goverment } \\
\text { benefus }\end{array}$ & 8 & $[9], 17],[12],[3],[30]$ & {$[10],[77,[31,, 30]$} & {$[10],[2][33]$} \\
\hline 8 & Info for a gor enmert job & 11 & $\begin{array}{c}\text { [34], [35], [23], [36], (9)] } \\
\text { [10], [11], [12] }\end{array}$ & $[23],[36],(10],[12],[3]]$ & [36], \\
\hline 9 & Entetaimment & 7 & $\begin{array}{c}{[10],(38),[0],[39]} \\
{[12],[31],[37]}\end{array}$ & [37) & \\
\hline 10 & Education & 24 & 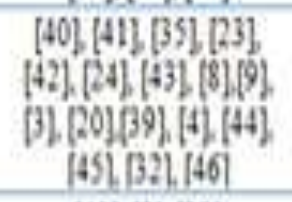 & $\begin{array}{c}{[24][20],[39],[45],[47],[16]} \\
{[11],[38],[15],[14]}\end{array}$ & $\begin{array}{c}{[24][39][45,[46],[14],} \\
{[6]}\end{array}$ \\
\hline II & Family Institution & 6 & {$[40,[9],[39]$} & $[9],[3],[39], 48],[12]$ & [3], \\
\hline 12 & Persoall Identíczion & 4 & (40L1391 & [201/391/481 & [201394.148] \\
\hline 13 & Businesppupose & 9 & $\begin{array}{l}{[199,[300,[10],[50],} \\
[123],(51),(52)]\end{array}$ & $\begin{array}{c}{[49],[30],[10],[4],[53],[50]} \\
{[31]}\end{array}$ & [30][51] \\
\hline 14 & Bankna Purpose & 7 & 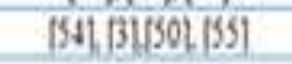 & {$[34,[31,191,150 t, 535,1301$} & 1121,1531 \\
\hline & & & 66 & 80 & 49 \\
\hline
\end{tabular}

Based on the list of the usage pattern of government online information for different generations in Table 3, we found that 'education purpose' is the most commonly investigated usage pattern, which accounts for 24 studies. This is followed by 'safety or healthy advice' and 'government public policy information' with 16 studies and 12 studies respectively. Both of 'tourism information' and 'government job vacancy' contribute to 11 studies for each. The others, namely the 'government agency services' and "business purpose" were found in nine studies, 'government benefits' and 'download government form' in eight studies, 'entertainment', 'banking purpose' and 'religious info' in seven studies, and 'family institutions registration' in six studies. Additionally, the 'personal identification' is the least studied which is found in four studies. Results of the review show that 'education purpose' is the most significance usage pattern for using government online information.

Next, we discussed the comparison of related works in satisfaction and loyalty enhancement for using government online information. For each of the paper, we identified the type of contribution, and detail information of their contribution. The results are presented in Table 4. 
Table 4: Approaches, Tools, Method/Techniques and Framework of Satisfaction and Loyalty

\begin{tabular}{|c|c|c|c|c|}
\hline \multirow[t]{2}{*}{ PaperId } & \multicolumn{4}{|c|}{ Contribution } \\
\hline & $\begin{array}{l}\text { Approach / } \\
\text { case study }\end{array}$ & $\begin{array}{l}\text { Framework/ } \\
\text { Model }\end{array}$ & $\begin{array}{l}\text { Experiment/ } \\
\text { Literature study }\end{array}$ & Detail \\
\hline [56] & & / & / & $\begin{array}{l}\text { Comprehensive theoretical model of social interaction and its } \\
\text { antecedents that explain how digital natives develops trust and } \\
\text { loyalty }\end{array}$ \\
\hline [57] & & 1 & & $\begin{array}{l}\text { Develop complexity of age-aware E-Govemment for instance, an } \\
\text { age-aware Technology Acceptance Model for E-Govemment }\end{array}$ \\
\hline [58] & & $/$ & & E-leaming system success model \\
\hline [59] & & l & & $\begin{array}{l}\text { A model of citizen loyalty with govemment online self-service } \\
\text { delivery options. }\end{array}$ \\
\hline [60] & & l & & Partial Least Squares Path Modelling (PLS- PM) technique \\
\hline [61] & I & & & Design of adaptive interface for e-Gov services. \\
\hline [62] & / & $/$ & & $\begin{array}{l}\text { research was structured into three phases along the development } \\
\text { model of the ISO } 9241-210\end{array}$ \\
\hline [63] & 1 & I & & $\begin{array}{l}\text { Swedish Customer Satisfaction Barometer model (SCSB). A case } \\
\text { study in Pakistan }\end{array}$ \\
\hline [64] & / & l & & Systematic literature review on loyalty towards e-govemment \\
\hline [65] & & & I & Systematic literature review on loyalty towards e-govemment \\
\hline [66] & / & 1 & & $\begin{array}{l}\text { Develop a recognized model based on ACSI for measuring the } \\
\text { customer satisfaction index for the e-services in the Kingdom of } \\
\text { Bahrain (BHCSI). }\end{array}$ \\
\hline [68] & I & 1 & & $\begin{array}{l}\text { Technology Acceptance Model, Unified Theory of Acceptance,Case } \\
\text { study in China }\end{array}$ \\
\hline [69] & & & 1 & Challenges, Issues and Complexities \\
\hline [70] & 1 & & & $\begin{array}{l}\text { the main reason which inhibit readiness to use this e-govemment } \\
\text { service in Poland }\end{array}$ \\
\hline Total & 7 & 10 & 3 & \\
\hline
\end{tabular}

The list of related works in satisfaction and loyalty are presented in a table of comparison as shown in Table 4. Table 4 shows the comparison analysis of the approach, framework, model and method involved in using government online information. Referring to the contribution aspect in Table 4, most of the existing works focus on developing model, frameworks and approach, while limited works were involved in conducting experiment and literature study and none was reported on developing tools and approach. The finding indicates that there is no outstanding work of user based design model to enhance loyalty and satisfaction of using government online information.

\section{APPROACH/FRAMEWORK/MODEL IN ENHANCING LOYALTY AND SATISFACTION OF USING GOVERNMENT INFORMATION ONLINE.}

Some work has been performed to analyze online government information improvement in its loyalty and satisfaction. For instance[ 6] evaluated the satisfaction and allegiance of government-related websites across e-government and e-business. The research gathered information from the American Customer Satisfaction Index (ACSI) and used structural equation modelling to compare the determinants and the results of satisfaction across these sectors. In this research a sample of survey responses were gathered from e-users and e-government websites. Model results demonstrate that while for e-business customers some similarities exist, satisfaction mainly depends on the website's personality, while satisfaction with e-government is determined more similarly by multiple predictors.

In an attempt to examine the loyalty and satisfaction of users towards government information online, [62] conducted a survey through a developed questionnaire distributed. Then, they analyzed the data by using appropriate statistical methods and tested the hypotheses of this study, involving loyalty and satisfaction of customers.

In the study context of integrated, interoperable transactional e-services, supplied by the Saudi Ministry of Higher Education (MOHE), the study also[ 66] created a conceptual framework that explains citizen allegiance to e-government self-service offering alternatives. The suggested model was empirically evaluated by the linear various regression assessment of 402 study responses from Saudi citizens / users of transactional e-services.

The research was performed to identify, after the e-government facilities supplied by the Pakistan Punjab Province e-government portal, the most important factor for the satisfaction of Pakistani people. However, the public loyalty was not investigated. Even if their study results are only limited to Pakistan, we believe the technique can be replicated to study factors of allegiance.

[1] emphasized on loyalty and satisfaction in using government information online. However, they only focused on senior citizen only. In this research, they conducted empirical research to examine the satisfaction of senior citizens with e-government portals. Thirdly, the study included the concept of social influence as the determinant of senior citizen satisfaction and loyalty with e-government portals. They also found supporting evidence for the argument. 
In the last few years, researchers have witnessed the development model to enhance satisfaction and loyalty by using government information online. For example, [65] discussed satisfaction of the consumers. Their research aims to evaluate the achievement of e-government with the satisfaction of the citizen and to explore its relations with the then performs a systematic study of the Swedish random citizen, which receives 425 valid replies. The most interesting thing is that they have explained in detail how to improve IT consumers ' satisfaction. Citizen satisfaction with e-government services is, in order to simplify the way in which they explain it, connected with citizens ' view of internet services (transaction), information security (transparency) and digital communication (interactivity) in terms of evaluating performance and service results.

\section{CONCLUSION}

An analysis of methods, approaches and model of satisfaction has been conducted. A list of existing works related to satisfaction has been presented in Table 4. Based on the analysis of existing works, work on user based design model to enhance user satisfaction using government online information is still non-existence. Moreover, most of the works in satisfaction focus on the services. Despite that, approach, framework, model and method involves various domains, which are e-government, education, and IT. Most of the existing works focus on developing model and frameworks and method while limited works were involved in developing tools and approach. The finding indicates that there is no outstanding work of satisfaction using online information in governments especially based on different generation. For future work, we plan to develop a user based design model to enhance user satisfaction using government online information as guideline and reference to the government in identifying the user satisfaction toward government online information.

\section{ACKNOWLEDGEMENT}

The authors would like to thank the Universiti Teknikal Malaysia Melaka and Abu Dhabi Police for their support throughout this research.

\section{REFERENCES}

1. G. Ordun, "Millennial (Gen Y) Consumer Behavior, Their Shopping Preferences and Perceptual Maps Associated With Brand Loyalty," Can. Soc. Sci., vol. 11, no. 4, pp. 40-55, 2015.

2. A. J. A. M. van Deursen and E. J. Helsper, "A nuanced understanding of Internet use and non-use among the elderly,” Eur. J. Commun., vol. 30, no. 2, pp. 171-187, 2015.

3. L. M. Kaiser, "GENERATIONAL DIFFERENCES IN PREFERENCE FOR INTERACTIVITY," 2011.

4. M. C. Yousef, "Satisfaction, challenges, and interaction in online education: A generational comparison," ProQuest Diss. Theses, no. December, p. 192, 2012.

5. Berlilana, T. Hariguna, and Nurfaizah, "Understanding of Public Behavioral Intent to Use e-Government Service: An Extended of Unified Theory of Acceptance Use of Technology and Information System Quality," Procedia Comput. Sci., vol. 124, pp. 585-592, 2017.

6. S. Badowska, A. Zamojska, and A. Rogala, "Baby performance of the e-government services. The researcher

Boomers' Attitudes toward Innovations: Empirical Research in Poland," Procedia - Soc. Behav. Sci., vol. 213, pp. 1050-1056, 2015.

7. P. Naidoo, P. Ramseook-Munhurrun, N. V. Seebaluck, and S. Janvier, "Investigating the Motivation of Baby Boomers for Adventure Tourism," Procedia - Soc. Behav. Sci., vol. 175, pp. 244-251, 2015.

8. L. C. Fu and H. P. Yueh, "Baby boomers' behaviors and attitudes of newspaper reading: A comparison among three layouts," Proc. - IEEE 15th Int. Conf. Adv. Learn. Technol. Adv. Technol. Support. Open Access to Form. Informal Learn. ICALT 2015, pp. 120-121, 2015.

9. López Rivera Ibrahim, "Developing Online Trust in Electronic Commerce: a Generational Cohort Study in Puerto Rico," Proquest, p. 120, 2016.

10. E. R. R. Smith III, "Quasi-experimental study: Generational (Y, X, \& Boomer) reactions and learning effectiveness of asynchronous, mobile-based online learning versus asynchronous, computer-based online learning," 2014.

11. T. Olsson, U. Samuelsson, and D. Viscovi, "Resources and repertoires: Elderly online practices," Eur. J. Commun., p. 026732311881085, 2018.

12. T. Nam, "Determining the type of e-government use," Gov. Inf. Q., vol. 31, no. 2, pp. 211-220, 2014.

13. G. Tuteja, "A Study of Exploratory Tendencies for Mobiles across Generations," vol. 3, no. November, pp. 70-77, 2015.

14. K. Gasova and K. Stofkova, "E-Government as a Quality Improvement Tool for Citizens' Services," Procedia Eng., vol. 192, pp. 225-230, 2017.

15. E. Hernández-Encuentra, M. Pousada, and B. Gómez-Zúñiga, "ICT and Older People: Beyond Usability," Educ. Gerontol., vol. 35, no. 3, pp. 226-245, 2009.

16. R. M. Leavitt, "GENERATIONAL DIFFERENCES IN WORK MOTIVATION OF HEALTHCARE WORKERS," 2014.

17. H. Yan and Y. Ting, "The Effectiveness of Online Citizen Evaluation of Government Performance: A Study of the Perceptions of Local Bureaucrats in China," Public Pers. Manage., vol. 47, no. 4, pp. 419-444, 2018.

18. K. Farrell and R. D. Goldman, Generations and Level of Information on Mobile Devices Usage: An Entropy-Based Study, vol. 53, no. 6. Springer International Publishing, 2011.

19. S. Gardiner, D. Grace, and C. King, "Is the Australian domestic holiday a thing of the past? Understanding baby boomer, Generation X and Generation Y perceptions and attitude to domestic and international holidays," J. Vacat. Mark., vol. 21, no. 4, pp. 336-350, 2015.

20. U. U. Onye and Y. Du, "Digital natives and digital divide: Analysing perspective for emerging pedagogy," Proc. IADIS Int. Conf. Cogn. Explor. Learn. Digit. Age, pp. 324-328, 2016.

21. R. Burke, C. Cooper, and A.-S. Antoniou, "The Multi-generational and Aging Workforce," no. November, 2015.

22. S. Özdemir and E. Utkun, "The Role of Online Social Network Travel Websites in Creating Social Interaction for Gen Y Travelers," Ind. Textila, vol. 66, no. 4, pp. 209 $217,2015$.

23. M. Kubiatko, "The Comparison of Different Age Groups on the Attitudes toward and the Use of ICT," Kuram Ve Uygulamada Egit. Bilim., vol. 13, no. 2, pp. 1263-1272, 2013. 
24. J. Foecke, "A Multiple Case Study Approach to Explore Generational Theory to Enhance Online Continuing Nursing Education," no. June, 2017.

25. M. B. Mollah, K. R. Islam, and S. S. Islam, "E-police system for improved E-government services of developing countries," 2012 25th IEEE Can. Conf. Electr. Comput. Eng. Vis. a Greener Futur. CCECE 2012, no. May, 2012.

26. N. Wills-Johnson, "Digital Natives, Digital Immigrants: Dichotomy or Diversity in Psychiatric Nursing?," Econ. Voice, vol. 3, no. 8, pp. 1-2, 2006.

27. L. L. Alpay, P. J. Toussaint, N. P. M. Ezendam, T. A. J. M. Rövekamp, W. C. Graafmans, and R. G. J. Westendorp, "Easing Internet access of health information for elderly users," Health Informatics J., vol. 10, no. 3, pp. 185-194, 2004.

28. H. yi S. Tsai, R. Shillair, S. R. Cotten, V. Winstead, and E. Yost, "Getting Grandma Online: Are Tablets the Answer for Increasing Digital Inclusion for Older Adults in the U.S.?," Educ. Gerontol., vol. 41, no. 10, pp. 695-709, 2015.

29. K. J. Moore, A. Gauri, and T. Koru-Sengul, "Prevalence and sociodemographic disparities of Hepatitis C in Baby Boomers and the US adult population," J. Infect. Public Health, vol. 12, no. 1, pp. 32-36, 2018.

30. S. Dhanapal, D. Vashu, and T. Subramaniam, "Perceptions on the challenges of online purchasing: A study from 'baby boomers', generation ' $\mathrm{X}$ ' and generation ' $\mathrm{Y}$ ' point of views," Contaduria y Adm., vol. 60, pp. 107-132, 2015.

31. C. Wukich and I. Mergel, "Reusing social media information in government," Gov. Inf. Q., vol. 33, no. 2, pp. 305-312, 2016.

32. F. Sá, Á. Rocha, and M. Pérez Cota, "From the quality of traditional services to the quality of local e-Government online services: A literature review," Gov. Inf. Q., vol. 33, no. 1, pp. 149-160, 2016.

33. M. Stafford and D. Kuh, "Expectations for future care provision in a population-based cohort of baby-boomers," Maturitas, vol. 116, no. March, pp. 116-122, 2018.

34. D. S. Lyons, "How millennials and generation $\mathrm{Z}$ are redefining work," Chang. Gener. Rep., pp. 1-140, 2017.

35. C. Ellington, "Gen Y: The Influence of E-Recruitment Techniques,” Diss. Manuscr., no. May, pp. 1-330, 2017.

36. A. Kurniawati, T. M. A. Arisamadhi, and I. I. Wiratmadja, "Relationship among individual factors, knowledge sharing, and work performance: A model from baby boomers, generation X, and generation y perspective," IEEE Int. Conf. Ind. Eng. Eng. Manag., vol. 2016December, pp. 6-10, 2016.

37. B. J. Jansen, K. Sobel, and G. Cook, "Gen X and Ys attitudes on using social media platforms for opinion sharing," Proc. 28th Int. Conf. Ext. Abstr. Hum. factors Comput. Syst. - CHI EA '10, p. 3853, 2010.

38. C. J. Williams, J. J. Matt, and F. L. O'Reilly, "Generational Perspective of Higher Education Online Student Learning Styles," J. Educ. Learn., vol. 3, no. 2, 2014.

39. K. L. Burek, "Advancements in Professional Generations," 2018.

40. L. R. Angeningsih and B. Sirisunyaluck, "CT Usage: Self-Assessment of Critical Issues Facing Indonesia and Thai Gen Y Students ' Future by 2030," pp. 167-179, 2000.

41. R. J. G. Stevens and N. M. Hamilton, "Is there a digital generation gap for e-learning in plastic surgery?," J. Surg. Educ., vol. 69, no. 3, pp. 344-349, 2012.

42. V. Obradovic, Z. Mitrovic, and M. Pavicevic, "Millennials vs. Baby Boomers in project management: Education and training gap," Proc. 12th Int. Sci. Tech. Development: Improving Training Programs Across

Conf. Comput. Sci. Inf. Technol. CSIT 2017, vol. 2, pp. 22-29, 2017

43. E. J. H. Alexander J. A. M. van Deursen, "The ThirdLevel Digital Divide: Who Benefits Most from Being Online?," Commun. Inf. Technol. Annu., vol. 2, no. 1, pp. 1-6, 2011.

44. C. A. Adams and P. Pente, "Teachers teaching in the new mediascape: Digital immigrants or "natural born cyborgs'?," E-Learning Digit. Media, vol. 8, no. 3, pp 247-257, 2011.

45. E. Instefjord, "Appropriation of digital competence in teacher education," Nord. J. Digit. Lit., vol. 2015, no. 4, pp. 155-171, 2015.

46. H. Ting, T. Y. Lim, E. C. de Run, H. Koh, and M. Sahdan, "Are we Baby Boomers, Gen X and Gen Y? A qualitative inquiry into generation cohorts in Malaysia," Kasetsart J. Soc. Sci., vol. 39, no. 1, pp. 109-115, 2018.

47. W. Nadeem, D. Andreini, J. Salo, and T. Laukkanen, "Engaging consumers online through websites and social media: A gender study of Italian Generation Y clothing consumers,” Int. J. Inf. Manage., vol. 35, no. 4, pp. 432442, 2015.

48. C. Ball, J. Francis, K.-T. Huang, T. Kadylak, S. R. Cotten, and R. V. Rikard, "The Physical-Digital Divide: Exploring the Social Gap Between Digital Natives and Physical Natives," J. Appl. Gerontol., p. $073346481773251,2017$.

49. S. H. W. Chuah, M. Marimuthu, J. Kandampully, and A Bilgihan, "What drives Gen Y loyalty? Understanding the mediated moderating roles of switching costs and alternative attractiveness in the value-satisfaction-loyalty chain," J. Retail. Consum. Serv., vol. 36, no. July 2016, pp. 124-136, 2017.

50. M. Muda, R. Mohd, and S. Hassan, "Online Purchase Behavior of Generation Y in Malaysia," Procedia Econ Financ., vol. 37, no. 16, pp. 292-298, 2016.

51. T. Chakraborty and J. Balakrishnan, "Exploratory tendencies in consumer behaviour in online buying across gen $\mathrm{X}$, gen $\mathrm{Y}$ and baby boomers," Int. J. Value Chain Manag., vol. 8, no. 2, p. 135, 2017.

52. A. Bilgihan, "Gen y customer loyalty in online shopping: An integrated model of trust, user experience and branding," Comput. Human Behav., vol. 61, pp. 103-113, 2016.

53. S. S. L. N. Mosupyoe, "Generational Differences In South African Consumers ' Brand Equity Perceptions," 2017.

54. L. Duva, "Generational Cohort Behaviors Toward Information Security And Its Effect On E-Commerce / E-Banking," 2018

55. N. P. Rana and Y. K. Dwivedi, "Citizen's adoption of an e-government system: Validating extended social cognitive theory (SCT)," Gov. Inf. Q., vol. 32, no. 2, pp. 172-181, 2015.

56. S. I. S. Al-hawary and S. M. Al-menhaly, "The Quality of E-Government Services and its Role on Achieving Beneficiaries Satisfaction," Glob. J. Manag. Bus. Res. A Adm. Manag., vol. 16, no. 11, 2016.

57. B. Niehaves and J. Becker, "The Age-Divide in E-Government - Data , Interpretations , Theory Fragments," Eur. Res. Cent. Inf. Syst., vol. 286, pp. 279287, 2013.

58. S. Matter, "Success of Government E-Service Delivery : Does Success of Government E-Service Delivery : Does Satisfaction Matter?," Int. Conf. Fed. Inf. Process., no. August, 2010. 
59. A. Chatfield, "Service quality, citizen satisfaction, and loyalty with self-service delivery options to transforming e- government services," Univ. Wollongong Res. Online Fac., vol. 1, pp. 1-11, 2013.

60. C. S. Yap, R. Ahmad, C. Mason, and F. T. Newaz, "Satisfaction with E-Government Portals : Perspective of Senior Citizens," Proc. ofthe 9th Int. Jt. Conf. Knowl. Discov. Knowl. Eng. Knowl. Manag., no. Kmis, pp. 4149, 2017.

61. G. Gronier, "Quality of services and citizen profiling in e-Government," Gov. Inf. Q., vol. 26, pp. 82-88, 2013.

62. T. Molnar, "Improving Usability of e-Government for the Elderly," Electron. Jounral E-Government, vol. 13, no. 2, pp. 122-135, 2015.

63. A. G. Mastoi and N. Gul, "Evaluating Citizen e-Satisfaction from e-Government Services: A Case of Pakistan,” Eur. Sci. J. Febr., vol. 12, no. 5, pp. 346-370, 2016.

64. B. Davey, K. R. Parker, and K. R. Parker, "e-Government and the Elderly: A Two Country Comparison," AMCIS 2011 Proc., no. June 2014, 2011.

65. F. V. M. Iii, "Comparing determinants of website satisfaction and loyalty across the e-government and e-business domains," Electron. Gov. An Int. J., vol. 8, pp. 164-184, 2011.

66. J. Al-ammary, R. Al-kaabi, A. Al-soufi, H. Ali, and A. Alrayes, "Assessment of e-Government Services from the Supply Side to the Demand Side: Towards Better e-Services in the Kingdom of Bahrain," Int. J. Econ. Res., no. January, pp. 28-55, 2017.

67. S. I. A. N. J. Hamza Ahmad Qureshi, Yaamina Salman, "A Systematic Review Of E-Government Evaluation," Pak. Econ. Soc. Rev., vol. 55, no. 2, pp. 355-390, 2017.

68. Y. Yang, "Towards a New Digital Era : Observing Local E-Government Services Adoption in a Chinese Municipality," Futur. Internet J., vol. 9, no. 53, pp. 1-17, 2017.

69. J. Choudrie, "Exploring E-Government in the UK: Challenges, Issues and Complexities Exploring E-Government in the UK: Challenges, Issues and Complexities," J. Inf. Sci. Technol., vol. 2, no. February, pp. 26-40, 2014.

70. J. Papinska, "Analysis Of Reasons For Citizens Low Interest In E-Government Services In Poland: E-Filing Case Study," Inf. Syst. Manag., vol. 2, no. 1, pp. 47-59, 2013. 